\title{
Meiofaunal emergence from intertidal sediment measured in the field: significant contribution to nocturnal planktonic biomass in shallow waters
}

\author{
W. Armonies \\ Biologische Anstalt Helgoland (Wadden Sea Institute Sylt); D-2282 List, \\ Federal Republic of Germany
}

\begin{abstract}
Field studies on the occurrence of meiobenthos in the water column above intertidal sandflats have been performed near the Island of Sylt in the northern Wadden Sea. Swimming meiobenthos was strongly dominated by harpacticoid copepods. Many of them have a semiplanktonic life-style. They rest in superficial sediment layers at low tide and swim in the water column at high tide. Swimming activity correlated negatively with light. The abundance in the water column was one order of magnitude higher during the night. Strong currents caused by storm tides significantly decreased meiobenthic abundance in the water column. Light and flow being constant, no significant changes of meiobenthic abundance per unit area occurred over a tidal cycle. Since holoplankton and meroplankton abundances correlated positively with the height of the water column, semiplanktonic meiobenthos may dominate the mesozooplankton in shallow waters. On an average, emergence of meiobenthos increased the mesozooplanktonic biomass by about $2 \%$ during diurnal high tides over the entire tidal cycle, and by about $50 \%$ during nocturnal high tides. Because of seasonal cycles of the dominant harpacticoids, this high contribution to planktonic biomass may be a summer phenomenon.
\end{abstract}

\section{INTRODUCTION}

Traditionally, meiobenthos was thought to be confined to either living in the sediment or its interstices, or performing an epibenthic life-style with intermittent hiding in the sediment. However, recent investigations revealed that at least some meiofaunal taxa may actively leave the sediment and swim in the water column (Alldredge \& King, 1977; Hobson \& Chess, 1979; Hammer, 1981; Sibert, 1981; Ohlhorst, 1982; Hicks, 1986; Walters \& Bell, 1986; recently reviewed by Palmer, 1988). Most of these studies deal with tropical to warm temperate subtidal habitats. Laboratory experiments on the emergence behaviour of boreal intertidal meiobenthos (Armonies, 1988a, b, c) yielded the following predictions: (1) Copepoda and Plathelminthes may actively enter the water column; Ostracoda perform an epibenthic life-style, and Nematoda, Gastrotricha and Oligochaeta seem to live endobenthically. (2). The copepod and plathelminth swimming activity correlates negatively with light, i.e. their abundance in the water column should be higher during nocturnal than during diurnal high tides. (3) Currents affect the abundance of active swimmers in the water column. Abundance should be highest at weak currents, decrease as currents become stronger, and increase again when the sediment becomes eroded. In the latter case, Nematoda, Gastrotricha and Oligochaeta should also be found 
in the water column. (4) The swimming activity of harpacticoid copepods and plathelminths is also affected by physical factors such as temperature, salinity, and oxygen. However, the effects of these factors seem to be species-specific and in most cases there is no general pattern. The potential benefits and risks of active swimming in the water column are discussed by Alldredge \& King $(1980,1985)$ and Armonies $(1988 a, c)$.

The present study combines field sampling in the water column and sediment to test for (1) the presence of active swimmers in the water column above boreal intertidal sandflats, (2) a light effect, and (3) a decrease in swimming activity during periods with stronger currents. (4) Another aim of this study is to quantify the contribution of swimming meiobenthos to the biomass of mesozooplankton.

\section{MATERIAL AND METHODS}

\section{Study sites and sample collection}

Meiobenthic emergence into the water column was studied at the extensive tidal flats of the Königshafen wadden area near the Island of Sylt in the North Sea. For a general description of the area see Reise (1985). Three sites were sampled between July and September 1988 (Fig. 1): (1) Site I was a $20 \times 20 \mathrm{~m}$ square of a sheltered sandy tidal flat NE of the village of List. The sediment was mainly composed of fine sand (median diameter $150 \mu \mathrm{m}$, sorting coefficient 1.5). During an average tidal cycle, this site was submerged for $4 \mathrm{~h}$ (approx. $33 \%$ ) and the average height of the water column at high tide was $0.6 \mathrm{~m}$. (2) Site II was a $40 \times 10 \mathrm{~m}$ plot of medium sand (median diameter $324 \mu \mathrm{m}$, sorting coefficient 2.46) north of the village of List. The average submergence was $8 \mathrm{~h}$ per tidal cycle (approx. $66 \%$ ) and the average high water level was $1.1 \mathrm{~m}$. (3) Site III marks a series of 10 locations extending from site I to site II (distance approx. $300 \mathrm{~m}$ of shoreline) and further west to the Lister Haken. The total distance of shoreline covered by the 10 locations was about $600 \mathrm{~m}$, and individual locations were at least $50 \mathrm{~m}$ apart. The granulometric composition of the sediment varied from fine sand (site I) to coarse sand near the Lister Haken. The height of all locations was as at site I (i.e. about $33 \%$ of tidal submergence).

Sediment samples were collected at low tide using glass tubes of $1 \mathrm{~cm}^{2}$ inserted into the sediment to a depth of $2 \mathrm{~cm}$, thus only covering the brownish superficial sediment layers. Each set of both sediment and water samples consisted of at least 10 replicates. Three methods were applied to collect seawater samples above the intertidal sandflat. (1) Pipe samples were collected by vertically inserting plexiglas pipes of $10 \mathrm{~cm}^{2}$ and variable length $(0.3,0.5,1.0,1.5 \mathrm{~m}$ depending on the water depth) into the water column down to a few centimetres above the sediment. The pipe was closed with a rubber stopper at the upper end and withdrawn until the lower end was just below the water surface. The lower end was closed and then the pipe removed from the water. Such sampling yields a water column of $10 \mathrm{~cm}^{2}$ surface area reaching from the water surface to some $\mathrm{cm}$ above the sediment. Samples containing sand grains (by contact with the sediment surface) were rejected. To avoid artificial suspension of sediment and associated meiofauna, pipe samples were collected from a rubber dinghy which glided along a cable anchored at the sample site and the shore. The dinghy was pushed by hand along the cable, thus no oars or paddles disturbed the water layer or sediment surface. The cable also helped our 


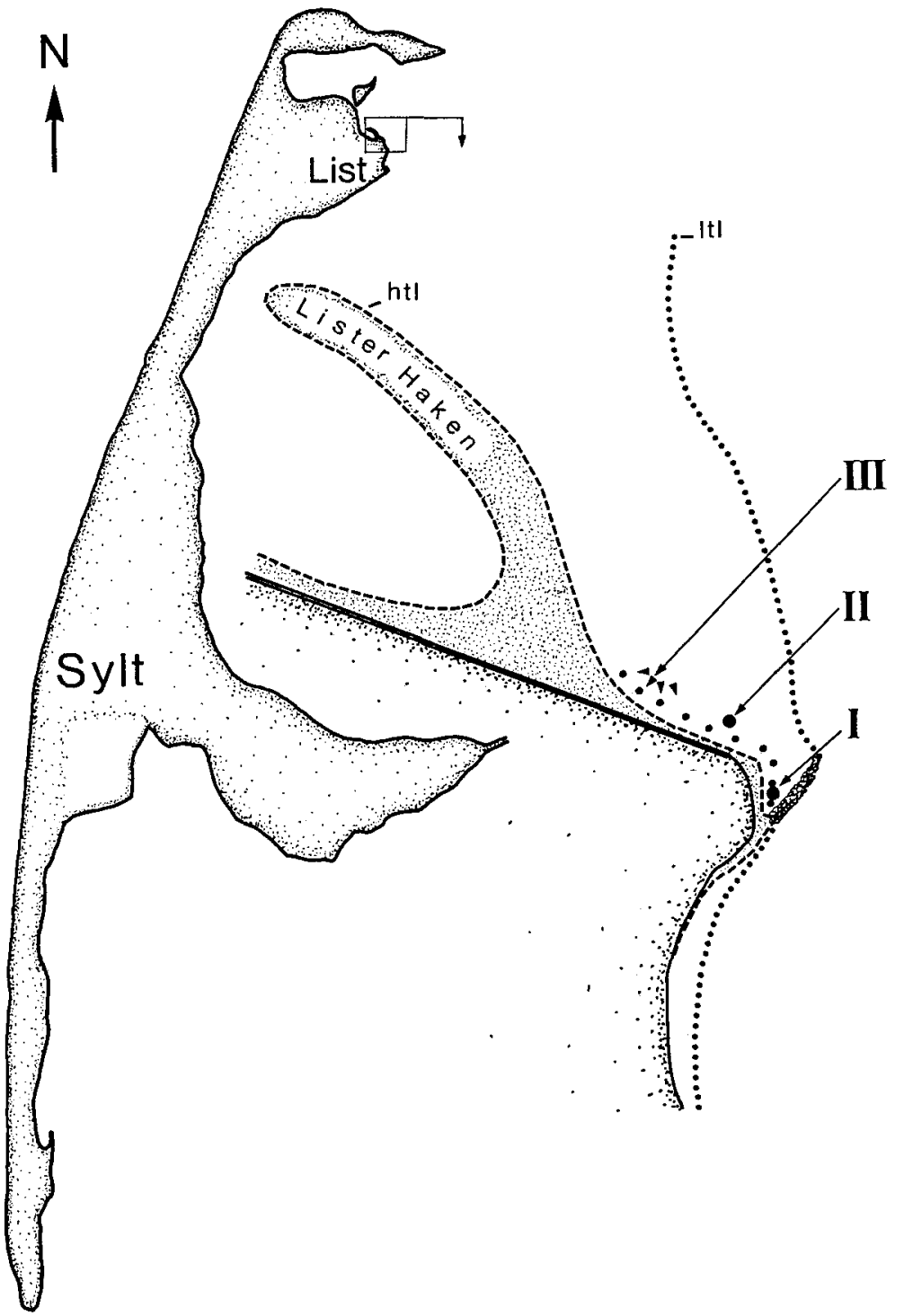

Fig. 1. Position of sampling sites (I, II, III) off the Island of Sylt in the northern Wadden Sea. htl $=$ high tide level, lt $=$ low tide level

return to the same locations in the case of repeated sampling during the tidal cycle (see below). (2) Samples of surface water were collected by scooping with a $12 \mathrm{dm}^{3}$ bucket with a rectangular opening (top $30 \mathrm{~cm}$ of the water column). (3) A $64 \mu \mathrm{m}$ plankton net with the opening fixed to a rectangular frame of $20 \times 40 \mathrm{~cm}$ was mounted onto a sledge to sample the water column horizontally between $10 \mathrm{~cm}$ (position of the lower opening of the frame above the sediment) and $50 \mathrm{~cm}$ above the sediment. A $12.5 \mathrm{~m}$ tow of this net 
filters $1 \mathrm{~m}^{3}$ of seawater. Such a sample from site II was used to estimate the individual biomass values of various taxa (see below).

Water samples were sieved through $63 \mu \mathrm{m}$ meshes and the remainder returned to the laboratory. The sediment and net samples were immediately preserved in $5 \%$ formalin. From the other water samples, animals were sorted alive using a dissecting microscope, and hard bodied meiofauna was subsequently preserved in $5 \%$ formalin for later counting and identification. All metazoan taxa except copepod nauplii (harpacticoid as well as calanoid) were counted but specimens that were retained on a $500 \mu \mathrm{m}$ sieve (e.g. shrimps, brachyuran megalopae) were excluded from later analysis.

\section{Testing for diurnal differences of meiobenthic emergence}

At site III, a $10 \mathrm{dm}^{3}$ sample of surface seawater was scooped from each of the 10 locations, once during daytime at high tide (August 27th), and once during the succeeding nocturnal high tide (August 28th). Abundance of the various taxa in the water samples is compared by Wilcoxon's matched pair signed rank statistic applied to the diurnal and nocturnal samples in each of the 10 locations. During the daytime sampling, the wave height was $5 \mathrm{~cm}$ in the most sheltered and up to $15 \mathrm{~cm}$ in the most exposed locations. There was less wind during the night and the wave height was mostly below $5 \mathrm{~cm}$ with a maximum of $10 \mathrm{~cm}$ at one location.

\section{Influence of strong currents}

Laboratory experiments suggest decreased abundance of semiplanktonic species in the water column as flow increases above a current speed of approx. $1 \mathrm{~cm} \cdot \mathrm{s}^{-1}$ (Armonies, 1988b; current speed measured $1 \mathrm{~cm}$ above the sediment surface). At the Island of Sylt, westerly gales greatly increase the current speed in the Wadden area and increase the high tide level. Water samples of $1 \mathrm{dm}^{3}$ volume (pipe samples from the top $1 \mathrm{~m}$ of the water column) were collected during two nights with westerly storms (September 11 th, $\mathrm{n}=24$, and September 12th, $\mathrm{n}=20$ ) at site II. Abundance of the various taxa was compared with the daytime water samples of September 8th, collected at the same site with the same method $(\mathrm{n}=24)$ but during periods where there were only slight winds. In all cases, sample collection started $1 \mathrm{~h}$ after highest water level (falling tide). On September 8th (daytime), the water level did not significantly differ from the average $\left(1.0 \mathrm{~m}, 1 \mathrm{~h}\right.$ after high tide). The surface current speed was about $10 \mathrm{~cm} \cdot \mathrm{s}^{-1}$ (measured by drifting objects). During the stormy nights, the tidal height was increased to 1.3 and $>1.5 \mu \mathrm{m}$, and the surface current velocity was about $0.5 \mathrm{~m} \cdot \mathrm{s}^{-1}$ and $0.8 \mathrm{~m} \cdot \mathrm{s}^{-1}$ on September 11 th and 12 th, respectively.

\section{Quantification of meiobenthos in the water column}

This was done using pipe samples of the entire water column from a rubber dinghy. Each of the seawater samples at each of the sampling dates consisted of 10 replicate water columns collected at least $2 \mathrm{~m}$ apart over a total distance of $20 \mathrm{~m}$ (site I) or $30 \mathrm{~m}$ (site II). In the July samples, each of the replicates was separately transferred into plastic bottles while the 10 replicates of the August and September samples were pooled. 
Depending on the actual height of the water column, the volume of collected seawater varied between 0.7 and $12 \mathrm{dm}^{3}$ per 10 replicates. There were 5 sampling occasions: (1) July 10th, $2 \mathrm{~h}$ before nocturnal high tide $(=\mathrm{ht}-2 \mathrm{~h})$, at site II (2) July 12th, daytime, site I, $h t-2 h$, ht $-1 \mathrm{~h}, \mathrm{ht}+1 \mathrm{~h}, \mathrm{ht}+2 \mathrm{~h}$; (3) July $13 \mathrm{th}$, nighttime, site I, ht $-2 \mathrm{~h}, \mathrm{ht}-1 \mathrm{~h}$, $\mathrm{ht}+1 \mathrm{~h}$; (4) August 8th, nighttime, and (5) September 9th, daytime, site II. Nineteen sampling dates distributed over the entire tidal cycle: at first, 6 samplings were carried out at $15 \mathrm{~min}$ intervals, starting $15 \mathrm{~min}$ after the sample site had been reached by the incoming tide; then, at 30 min intervals until the tide left the site again (see Figs $1,2,3$ ). Light, air and seawater temperature, tidal height, and wave height were monitored at the same intervals.

\section{Biomass estimation}

A $64 \mu \mathrm{m}$ plankton net sample from site II (August 11th) was used to determine the average individual dry weights of the dominant zooplankters and meiobenthic taxa, following the procedure described by Widbom (1984) for formalin-preserved specimens. These determinations for the more abundant taxa, and literature data from Widbom (1984), Hickel (1975), and Faubel (1982) were fitted according to the actual percentages of size classes in the above net sample and thus yielded the following average individual dry weights (all in $\mu \mathrm{g}$ ) used for biomass calculation: holoplanktonic Appendicularia and Chaetognatha 1.0, calanoid copepods 1.5 (including copepodites but excluding nauplii), planktonic Plathelminthes 1.0, Rotatoria 0.2 (estimate); meroplanktonic taxa, nectochaeta larvae and barnacle nauplii 0.3 , barnacle cypris larvae 3.0, spionid larvae 5.0, juvenile (5 to 6-setiger) Arenicola marina L. and trochophore larvae 1.0; semiplanktonic harpacticoids 0.8 (including copepodites but excluding nauplii), cyclopoids 0.3 , plathelminths 1.0; benthic Ostracoda 2.0, Nematoda 0.5, and Plathelminthes 1.0 (all $\mu \mathrm{g} \mathrm{DW}$ ).

\section{Statistical analysis'}

Abundance data of both meiobenthic and planktonic taxa frequently deviated from a normal distribution (significant deviation of the variance-to-mean ratio from the appropriate reference of a chi-square table, $p=0.05$, Gage \& Geekie, 1973). In some cases, the 10 replicates forming a sample were pooled and thus no information is available on the between-replicate variation of abundances. Therefore, only non-parametrical methods are used: Wilcoxon's matched pair signed rank statistics, U-test (Wilcoxon et al, in Sachs, 1984), and Spearman's rank correlation coefficient (abbreviated by " $r_{s}$ "). Significant results are indicated by ${ }^{*}(p<0.05), \cdots(p<0.01)$ and $\cdots(p<0.001)$, respectively.

\section{RESULTS}

\section{Diurnal differences in the composition of mesozooplankton}

The daytime zooplankton above intertidal sandflats of the Wadden Sea is strongly dominated by holoplanktonic and meroplanktonic taxa which together comprise $>90 \%$ of metazoans. Abundances of these taxa are not significantly different in the nocturnal samples but swimming harpacticoids increased by an order of magnitude (Table 1). Therefore, holo- and meroplanktonic taxa each comprised less than $30 \%$ of the individu- 
Table 1. Abundances $\cdot 10 \mathrm{dm}^{-3}$ of seawater ( $\pm \mathrm{sd}$ ) and percentage composition of the metazoan fauna in diurnal and nocturnal plankton samples collected above an intertidal sandflat near the Island of Sylt (site III, August 27th and 28th, 1988). Copepod nauplii were excluded from this study. Minor taxa are not included in this table. Arenicola marina are all juveniles $<1 \mathrm{~mm}$ length. * denotes a significant difference between daytime and nighttime samples (Wilcoxon matched pair signed rank test, $\mathrm{p}<0.01$ )

\begin{tabular}{|c|c|c|c|c|c|c|}
\hline \multirow{2}{*}{$\begin{array}{l}\text { Taxon } \\
\text { Holoplankton, total }\end{array}$} & \multicolumn{2}{|c|}{$\begin{array}{l}\text { Daytime } \\
\text { Abundance }\end{array}$} & \multirow{2}{*}{$\frac{\%}{49}$} & \multicolumn{2}{|c|}{$\begin{array}{l}\text { Nighttime } \\
\text { Abundance }\end{array}$} & \multirow{2}{*}{$\frac{\%}{29}$} \\
\hline & 39.3 & $(18.1)$ & & 28.2 & $(13.7)$ & \\
\hline - Calanoidea & 26.1 & $(11.4)$ & & 19.8 & $(12.1)$ & \\
\hline - Rotatoria & 5.9 & $(5.2)$ & & 2.9 & $(2.7)$ & \\
\hline - Appendicularia & 5.6 & $(4,4)$ & & 3.9 & $(2.2)$ & \\
\hline - Chaetognatha & 1.0 & $(0.9)$ & & 0.7 & $(0.7)$ & \\
\hline - Plathelminthes & 0.5 & $(1.0)$ & & 0.4 & $(0.7)$ & \\
\hline Meroplankton, total & 33.8 & $(26.9)$ & 42 & 27.3 & (9.6) & 28 \\
\hline - Barnacle nauplii & 17.9 & $(15.5)$ & & 9.2 & (5.6) & \\
\hline - Barnacle cypris & 0.3 & $(0.5)$ & & 0.5 & $(0.7)$ & \\
\hline - Arenicola marina & 6.4 & (5.9) & & 8.5 & (7.3) & \\
\hline - Spionid larvae & 2.5 & $(2.2)$ & & 5.0 & $(3.6)$ & \\
\hline - Nectochaeta larvae & 4.1 & $(5.0)$ & & 3.2 & (3.1) & \\
\hline Semiplankton, total & 4.8 & $(2.6)$ & 6 & 40.4 & $(9.0)^{\cdots}$ & 41 \\
\hline - Harpacticoids & 4.5 & $(2.4)$ & & 39.5 & $(8.8)^{\cdots}$ & \\
\hline$-H$. flexus & 0.9 & $(0.9)$ & & 30.7 & $(5.8)^{\cdots}$ & \\
\hline - Ectinosomatidae & 0.3 & $(1.0)$ & & 5.3 & $(4.3)^{\cdots}$ & \\
\hline Benthos, total & 2.4 & $(3.0)$ & 3 & 2.0 & $(1.1)$ & 2 \\
\hline Total metazoans & 80.3 & $(34.7)$ & & 97.7 & $(21.5)$ & \\
\hline
\end{tabular}

als in the nocturnal water column while harpacticoids were the most abundant taxon with the species Harpacticus flexus Brady \& Robertson dominating. The percentage and abundance of suspended benthos (mainly Nematoda, Tardigrada and Ostracoda) are slightly higher in the daytime seawater samples, correlating with the higher waves. As $H$. flexus as well as some other species are very active swimmers which spend a substantial part of their life in the water column, they are henceforth denoted as "semiplankton" and thus separated from both entirely benthic species and species performing occasional migrations in the water column.

\section{Low abundance of semiplankton during stormy nights}

Increased current velocity during the stormy nights of September 11 th and 12 th was accompanied by an extraordinarily low abundance of semiplanktonic species in the water column. Compared to the daytime samples of September 8th, there was no significant increase in harpacticoid abundance during the stormy nights $10.33 \pm$ $0.56 \cdot \mathrm{dm}^{-3}$ versus $0.51 \pm 0.66$ and $0.45 \pm 0.76 \cdot 1 \mathrm{dm}^{-3}$ of seawater, $U$-test: $\mathrm{p}>0.1$ ) while all other nighttime samples $(n=24 \times 10$ replicates) yielded significantly higher abundances of semiplankton than the respective daytime samples (see below). 


\section{No changes of semiplanktonic abundance with tidal height}

Abundance of holoplankton and meroplankton in the water column above $100 \mathrm{~cm}^{2}$ of sediment surface correlates positively with the height of the water column $\left(r_{s}{ }^{*}{ }^{*} ;\right.$ Fig. 2$)$. In contrast, abundance of semiplankton per sediment surface unit remained fairly constant over the diel cycle but showed irregular variations at night (Fig. 2). Based on volume units of seawater, abundance of holo- and meroplankton remained fairly constant while the nocturnal abundance of both semiplankton and passively suspended benthos correlate negatively with tidal height $\left(\mathrm{r}_{\mathrm{s}}{ }^{* *}{ }^{*} ;\right.$ Fig. 3$)$. In the case of suspended benthos, the correlation is presumably caused by stronger wave erosion in shallow than in deep water. During the first 6 sampling dates, abundance of semiplankton shows a decrease which correlates significantly with increasing light during sunrise $\left(r_{s}^{*}\right)$.

\section{Nocturnal dominance of semiplankton}

In nocturnal shallow water, semiplankton can numerically dominate the zooplankton assemblage (Fig. 4). Semiplankton emerges from the sediment surface and the number of swimmers per surface unit remains rather constant over the tidal cycle. But increasing tidal height reduces their abundance per volume unit $\left(r_{s}{ }^{* *}\right)$. In contrast, holoplankton and meroplankton abundance per volume unit is rather constant, and increasing tidal height causes a higher abundance per surface unit $\left(\mathrm{r}_{\mathrm{s}}{ }^{* *}\right)$. On an average of the entire tidal cycles, semiplankton contributed $2.5 \%$ of metazoan abundance in the water column during daytime, and $47.8 \%$ at night (September and August samples, site II). In terms of biomass, the contribution is $2 \%$ and $32 \%$, respectively. The metazoan biomass may thus be about $50 \%$ higher at night. In the shallower water of site I, positioned higher up in the tidal gradient, the contribution of semiplankton to total mesozooplankton abundance may even exceed $60 \%$ (Fig. 5).

\section{Percentages of swimming harpacticoids}

During daytime high tide of September 7 th at site II, less than $1 \%$ of the harpacticoids present in the superficial sediment layer swam in the overlying water column (Table 2). In the nighttime samples of August 8th at the same site, an average of $66 \%$ of harpacticoids were simultaneously swimming in the water column. In the nighttime samples at site I (July 13th) as well as in some single sampling dates of August 8th (site II), the per surface area abundance of meiobenthic harpacticoids in the water column exceeded the abundance calculated from sediment sampling. This indicates a significant horizontal transport of harpacticoids with the tidal currents.

\section{Specific composition of harpacticoids}

During the entire period of investigation, the harpacticoid fauna of all sampled sites was strongly dominated by only two species, Harpacticus flexus and Tachidius discipes Giesbrecht. Together they comprised over $95 \%$ of the harpacticoids, in the water column as well as in the upper (top $2 \mathrm{~cm}$ ) sediment layer. Among the remaining species, Longipedia helgolandica, Canuella perplexa, Intermedopsyllus intermedius, Mesochra 

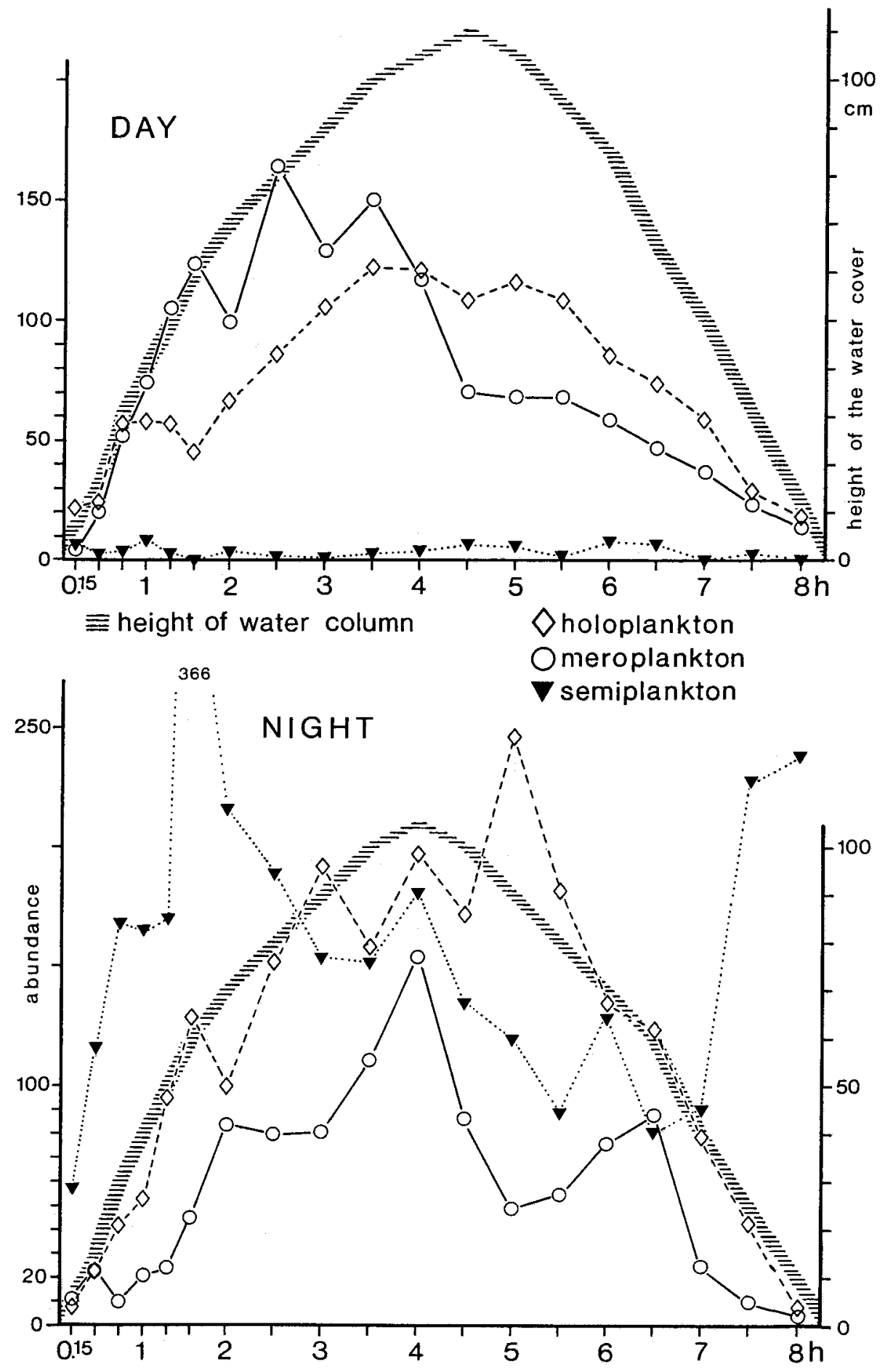
inconspicua, Evansula pygmaea, Paraleptastacus spinicauda and P. holsaticus, Enhydrosoma propinquum, Asellopsis hispida, and $A$. intermedia could be identified (authorities of all species can be referred to in Mielke, 1975). Ectinosomatids and some copepodites remained unidentified. All species occurred both in the water column and in superficial sediment.

\section{DISCUSSION}

\section{Specific composition of harpacticoid swimmers}

The joint occurrence of all identified harpacticoid species in both the water column above and in the superficial sediment layer of the intertidal sandflats may in part be an artefact of (1) the stronger sampling effort in the water column $(>500$ samples of seawater but only 50 sediment samples), and (2) may result from passive suspension of some of the rarer species by wave action and tidal currents or sediment rafting (Hicks, 1988). In any case, the species list is subject to seasonal change. For instance, pilot sampling performed since April 1988 often revealed high abundance of the diosaccid Amphiascoides debilis (Giesbrecht) in both the sediment and the water column. At the same time, the dominants of July to September, Harpacticus flexus and Tachidius discipes, were significantly less abundant. These findings correspond to the annual abundance cycles of the latter two species in a nearby semi-exposed sandflat (Mielke, 1976). Their high abundance in the water column therefore may be restricted to the summer months. It is not known, up to now, if there are other species that take over their role in the water column during winter.

$H$. flexus and $T$. discipes are both widely distributed in the Wadden Sea and the adjoining brackish waters (Noodt, 1957). This wide distribution may relate to high tolerance to salinity and sediment type (especially in $T$. discipes, Noodt, 1957) and coincide with high nocturnal swimming activity. Up to $75 \%$ of all $H$. flexus present in the sediment at low tide were simultaneously active in the water column during nocturnal high tide (Table 2). Therefore, the classification of this species as epibenthic seems no longer adequate, and a term such as semiplanktonic or semibenthic should be considered.

\section{Tidal transport of semiplankton}

In some cases, more harpacticoids were found in the water column than had been present in the sediment during the preceding low tide (Table 2). This demonstrates that high numbers of semiplanktonic species can be transported with the tidal currents and may explain some of the sudden changes of abundance in the sediment observed in previous studies (e.g. Palmer \& Brandt, 1981; Willems et al., 1984). The significant increase in semiplanktonic abundance in the water column during nighttime when compared to daytime sampling with similar hydrographic conditions, and the lack of such

Fig. 2. Abundance of holoplankton, meroplankton, and semiplankton (left ordinate) in the water column over $100 \mathrm{~cm}^{2}$ of sediment surface during a diel (Sept $7 \mathrm{th}$ ) and a nocturnal (Aug 8th) high tide (site II). Abscissa indicates time (h) since sampling site was reached by the incoming tide 

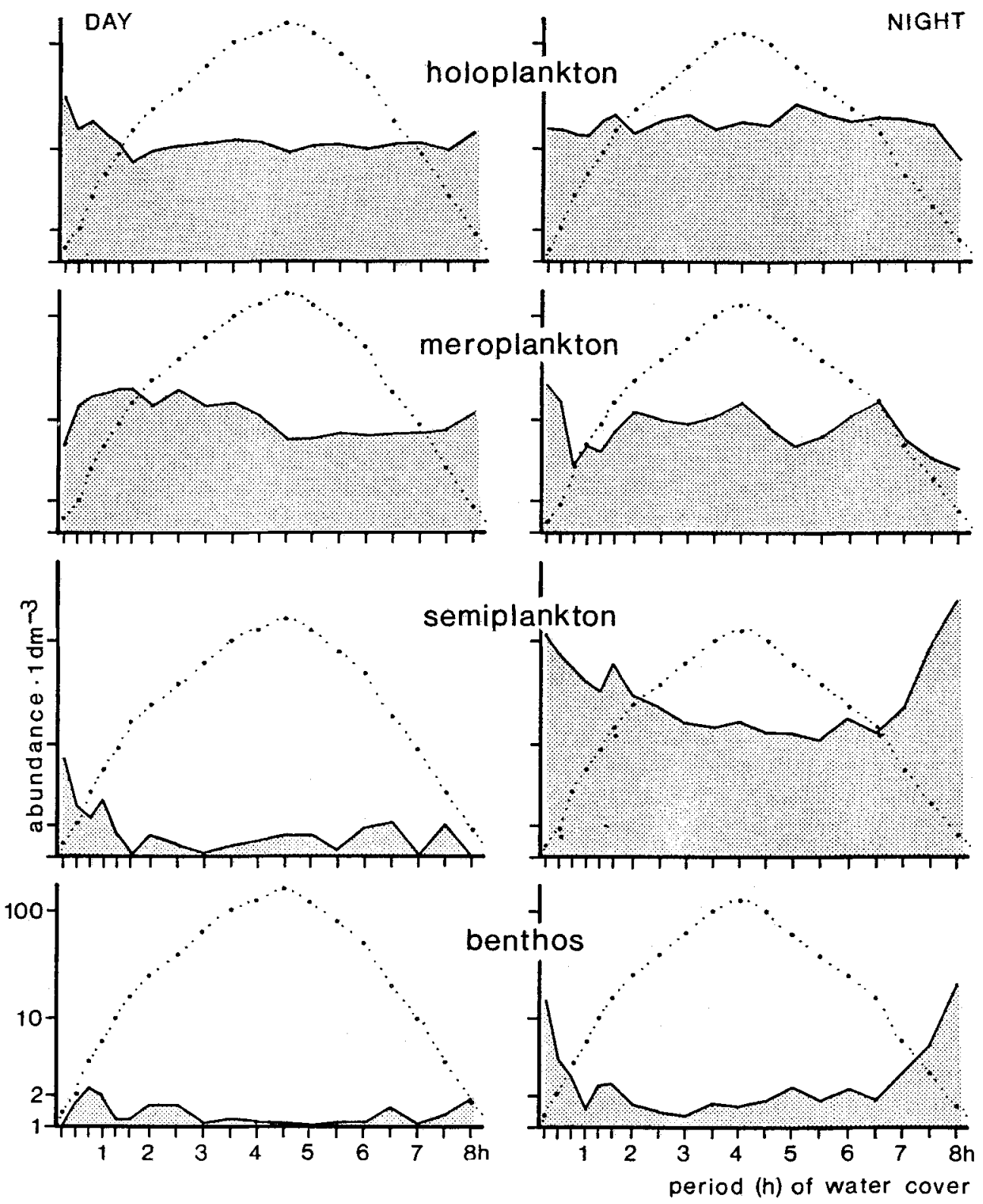

Fig. 3. Abundance $\left[\log (x+1)\right.$ transformed], per $1 \mathrm{dm}^{3}$ of seawater, of holo-, mero- and semiplankton and suspended benthos above an intertidal sandflat (site II) during daytime high tide of September 7 th and nocturnal high tide of August 8th. The dotted line indicates the height of the water cover 

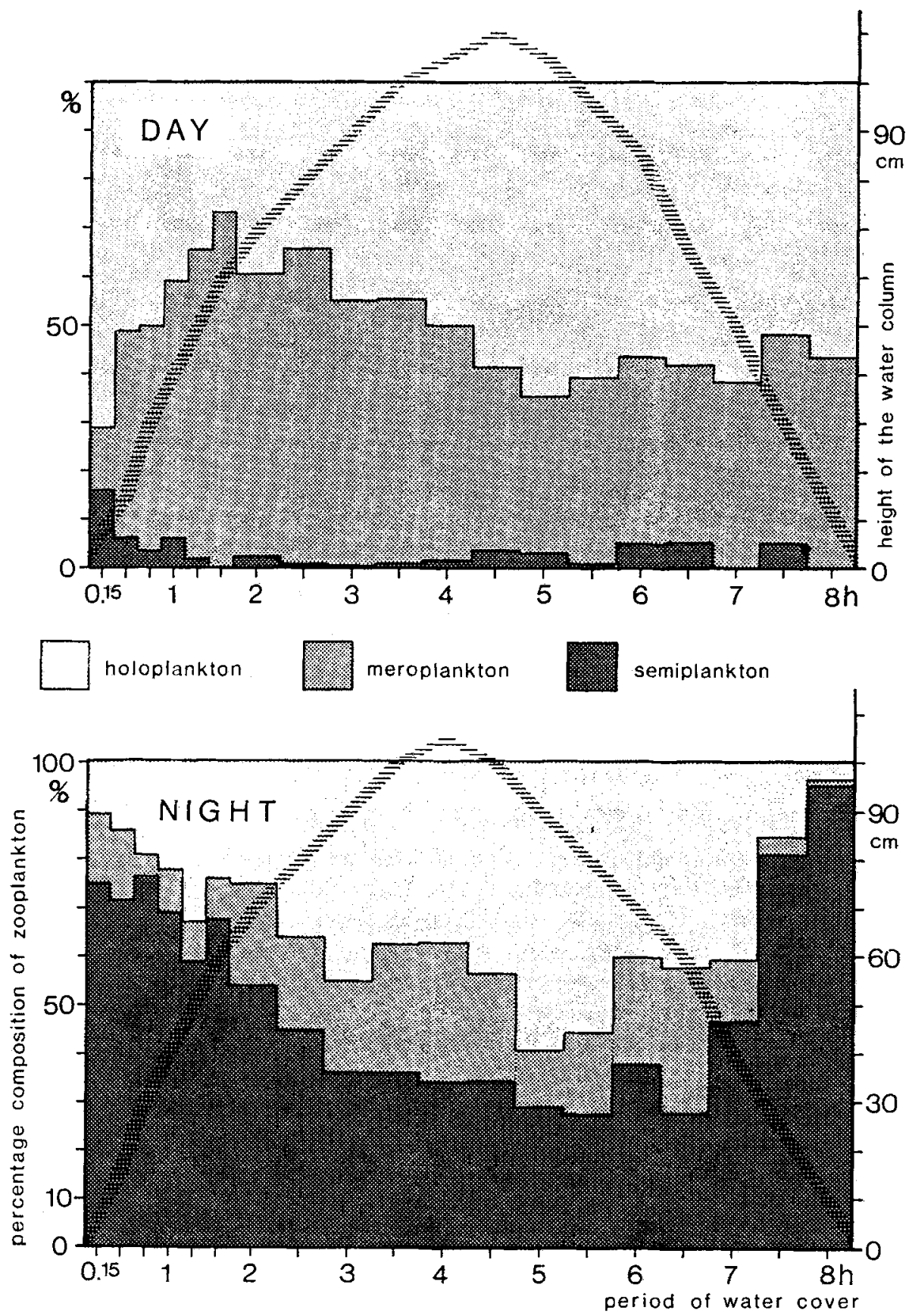

Fig.4. Percentage composition of zooplankton in the water column above an intertidal sandflat (site II) during daytime high tide of September 7th and the nocturnal high tide of August 8th. The diffuse line marks the actual height of the water column (right scale) 
Table 2. Average abundance of meiobenthic harpacticoids per $\mathrm{m}^{2}$ of sediment surface area and in the overlying water column. In July site I, sediment samples were only once collected (during the intermittent low tide). At the other dates, sediment samples were collected during the low tide preceding the high tide of water sample collection

\begin{tabular}{|c|c|c|c|}
\hline \multirow[b]{2}{*}{ Site and Date } & \multirow[b]{2}{*}{ Taxon } & \multicolumn{2}{|c|}{ Abundance in the } \\
\hline & & Water column & Sediment \\
\hline \multirow[t]{2}{*}{ (II) Sept. 7, daytime } & Total harpacticoids & 370 & 48,300 \\
\hline & $H$. flexus & 305 & 31,700 \\
\hline \multirow[t]{3}{*}{ (II) Aug. 8, nighttime } & Total harpacticoids & 15,730 & 23,700 \\
\hline & H. flexus & 14,000 & 18,700 \\
\hline & T. discipes & 1,320 & 4,200 \\
\hline (I) July 12 , daytime & Total harpacticoids & 2,030 & 4,200 \\
\hline (I) July 13 , nighttime & Total harpacticoids & 11,600 & 4,200 \\
\hline
\end{tabular}

an increase during stormy nights both corroborate the thesis that emergence is primarily an active process in this intertidal assemblage. Contrasting results from other geographic areas (i.e. prevalence of passive suspension of organisms, e.g. Palmer, 1984; Palmer \& Gust, 1985) may in part be explained by the non-linear response of harpacticoids to current speed (Armonies, 1988b). However, since emergence turned out to be a speciesspecific process (e.g. Walters, 1988) and most species have clear preferences for certain sediment properties correlating with the hydrographic conditions (e.g. Fenchel, 1978), variations in the degree of active swimming in the water column over sediment types are to be expected.

\section{Semiplankton worldwide significant in shallow waters}

The records of semiplanktonic species from other geographic areas (e.g. Hauspie \& Polk, 1973; Porter \& Porter, 1977; Hammer, 1981; Sibert, 1981; Fulton, 1984; Decho, 1986; Hicks, 1986; Jacoby \& Greenwood, 1988; Walters, 1988) indicate that emergence of sediment-associated meiofauna may occur on a worldwide scale. However, the high increase of planktonic biomass by swimming meiofauna is certainly restricted to shallow inshore waters. Their abundance in the water column relates to units of sediment surface area and their abundance per volume unit decreases with increasing water depth. Therefore, their contribution to planktonic biomass will strongly decrease in deeper waters (Fig. 5). Thus, sediment-associated meiofauna is only an insignificant component of traditional ship-operated plankton samples (e.g. Hickel, 1975; Martens, 1980). However, semiplanktonic swimmers may aggregate close to the sediment surface, as has been demonstrated by D'Amours (1988). In deeper waters they might therefore play a role in the suprabenthos.

\section{Semiplankton resembles macrofaunal suprabenthos}

Meiofaunal emergence from the sediment resembles the life-style of suprabenthic amphipods and cumaceans. They also spend the daytime in superficial sediment layers and enter the water column at night (e.g. Hesthagen, 1973; Sainte-Marie \& Brunel, 1985), 


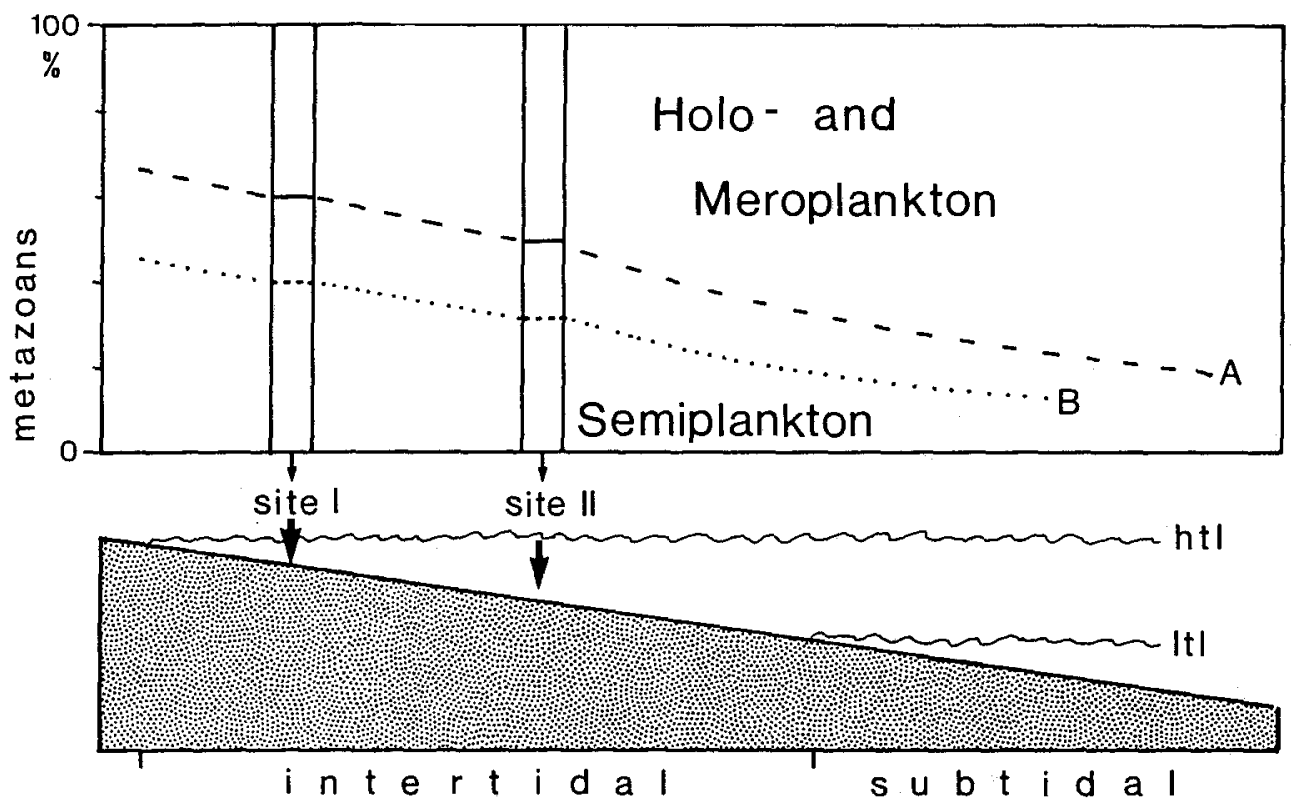

Fig. 5. Percentage composition of metazoans in the nocturnal water column at high tide above an intertidal sandflat (sites I, II) off the Island of Sylt, and the expected tendency along the tidal gradient. A: numerical abundance, B: biomass, htl, ltl: high and low tide level, respectively. For further explanations see text

although there were no significant dawn or dusk effects on swimming activity in the studied intertidal assemblage of harpacticoids (cf. Anger \& Valentin, 1976). Possibly, these similarities in life-style reflect convergently evolved reactions to factors like endobenthic predation, effective in all size classes of benthic organisms.

Acknowledgements. Thanks are due to Prof. Dr. K. Reise and an unknown reviewer for improving the manuscript by critical comments, and to Mr. B. Ipsen for his expertise in constructing the plankton sledge. This study was supported by a grant of the Biologische Anstalt Helgoland.

\section{LITERATURE CITED}

Alldredge, A. L. \& King, J. M., 1977. Distribution, abundance, and substrate preferences of demersal reef zooplankton at Lizard Island lagoon, Great Barrier Reef. - Mar. Biol. 41, 317-333.

Alldredge, A. L. \& King, J. M., 1980. Effects of moonlight on the vertical migration patterns of demersal zooplankton. - J. exp. mar. Biol. Ecol. 44, 133-156.

Alldredge, A. L. \& King, J. M., 1985. The distance demersal zooplankton migrate above the benthos: implications for predation. - Mar. Biol. 84, 253-260.

Amours, D. de, 1988. Vertical distribution and abundance of natant harpacticoid copepods on a vegetated tidal flat. - Neth. J. Sea Res. 22, 161-170.

Anger, K. \& Valentin, C., 1976. In situ studies on the diurnal activity pattern of Diastylis rathkei (Cumacea, Crustacea) and its importance for the "hyperbenthos". - Helgoländer wiss. Meeresunters. 28, 138-144. 
Armonies, W., 1988a. Active emergence of meiofauna from intertidal sediment. - Mar. Ecol. Prog. Ser. 43, 151-159.

Armonies, W., 1988b. Hydrodynamic factors affecting behaviour of intertidal meiobenthos. Ophelia 28, 183-193.

Armonies, W., 1988c. Physical factors influencing active emergence of meiofauna from boreal intertidal sediment. - Mar. Ecol. Prog. Ser. 49, 277-286.

Decho, A. W., 1986. Water-cover influences on diatom ingestion rates by meiobenthic copepods. Mar. Ecol. Prog. Ser. 33, 139-146.

Faubel, A., 1982. Determination of individual meiofauna dry weight values in relation to definite size classes. - Cah. Biol. mar. 23, 339-345.

Fenchel, T. M., 1978. The ecology of micro- and meiobenthos. - A. Rev. Ecol. Syst. 9, 99-121.

Fulton, R. S., 1984. Distribution and community structure of marine copepods. - Estuaries 7, 38-50.

Gage, J. \& Geekie, A. D., 1973. Community structure of the benthos in Scottish sea-lochs. II. Spatial pattern. - Mar. Biol. 19, 41-53.

Hammer, R. M., 1981. Day-night differences in the emergence of demersal zooplankton from a sand substrate in a kelp forest. - Mar. Biol. 62, 275-280.

Hauspie, R. \& Polk, P., 1973. Swimming behavior patterns in certain benthic harpacticoids (Copepoda). - Crustaceana 25, 95-103.

Hesthagen, I. H., 1973. Diurnal and seasonal variations in the near-bottom fauna - the hyperbenthos - in one of the deeper channels of the Kieler Bucht (Western Baltic). - Kieler Meeresforsch. 29, $116-140$.

Hickel, W., 1975. The mesozooplankton in the wadden sea of Sylt (North Sea). - Helgoländer wiss. Meeresunters. 27, 254-262.

Hicks, G. R. F., 1986. Distribution and behaviour of meiofaunal copepods inside and outside seagrass beds. - Mar. Ecol. Prog. Ser. 31, 159-170.

Hicks, G. R. F., 1988. Sediment rafting: a novel mechanism for the small-scale dispersal of intertidal estuarine meiofauna. - Mar. Ecol. Prog. Ser. 48, 69-80.

Hobson, E. S. \& Chess, J. R., 1979. Zooplankters that emerge from the lagoon floor at night at Kure and Midway atolls, Hawaii. - Fish. Bull. U.S. 77, 275-280.

Jacoby, C. A. \& Greenwood, J. G., 1988. Spatial, temporal, and behavioral patterns in emergence of zooplankton in the lagoon of Heron Reef, Great Barrier Reef, Australia. - Mar. Biol. 97, 309-328.

Martens, P., 1980. Beiträge zum Mesozooplankton des Nordsylter Wattenmeeres. - Helgoländer Meeresunters. 34, 41-53.

Mielke, W., 1975. Systematik der Copepoda eines Sandstrandes der Nordseeinsel Sylt. - Mikrofauna Meeresboden 52,1-134.

Mielke, W., 1976. Ökologie der Copepoda eines Sandstrandes der Nordseeinsel Sylt. - Mikrofauna Meeresboden 59, 1-86.

Noodt, W., 1957. Zur Ökologie der Harpacticoidea (Crust. Cop.) des Eulitorals der Deutschen Meeresküste und der angrenzenden Brackgewässer. - Z. Morph. Ökol. Tiere 46, 149-242.

Ohlhorst, S. L., 1982. Diel migration patterns of demersal reef zooplankton. - J. exp. mar. Biol. Ecol. $60,1-15$.

Palmer, M. A., 1984. Invertebrate drift: behavioral experiments with intertidal meiobenthos. - Mar. Behav. Physiol. 10, 235-253.

Palmer, M. A., 1988. Dispersal of marine meiofauna: a review and conceptual model explaining passive transport and active emergence with implications for recruitment. - Mar. Ecol. Prog. Ser. $48,81-91$.

Palmer, M. A. \& Brandt, R. R., 1981. Tidal variation in sediment densities of marine benthic copepods. - Mar. Ecol. Prog. Ser. 4, 207-212.

Palmer, M. A. \& Gust, G., 1985. Dispersal of meiofauna in a turbulent tidal creek. - J. mar. Res. 43, 179-210.

Porter, J. W. \& Porter, K. G., 1977. Quantitative sampling of demersal plankton migrating from different coral reef substrates. - Limnol. Oceanogr. 22, 553-556.

Reise, K., 1985. Tidal flat ecology. Springer, Berlin, $191 \mathrm{pp}$.

Sachs, L., 1984. Angewandte Statistik. Springer, Berlin, 552 pp.

Sainte-Marie, B. \& Brunel, P., 1985. Suprabenthic gradients of swimming activity by cold-water 
gammaridean amphipod Crustacea over a muddy shelf in the Gulf of Saint Lawrence. - Mar. Ecol. Prog. Ser. 23, 57-69.

Sibert, J. R., 1981. Intertidal hyperbenthic populations in the Nanaimo estuary. - Mar. Biol. 64, 259-265.

Walters, K., 1988. Diel vertical migration of sediment-associated meiofauna in subtropical sand and seagrass habitats. - J. exp. mar. Biol. Ecol. 117, 169-186.

Walters, K. \& Bell, S. S., 1986. Diel patterns of active vertical migration in seagrass meiofauna. - Mar. Ecol. Prog. Ser. 34, 95-103.

Widbom, B., 1984. Determination of average individual dry weights in different sieve fractions of marine meiofauna. - Mar. Biol. 84, 101-108.

Willems, K. A., Sharma, Y., Heip, C. \& Sandee, A. J. J., 1984. Long-term evolution of the meiofauna at a sandy station in Lake Grevelingen, The Netherlands. - Neth. J. Sea Res. 18, 418-433. 